\title{
Cysteine peroxidase activity in rat blood plasma
}

\section{A.V. Razygraev}

DO Ott Research Institute of Obstetrics \& Gynecology, RAMS, 3 Mendeleevskaja linija, St. Petersburg, Russia 199034

\begin{abstract}
Early studies recognized that the human extracellular glutathione peroxidase may function as cysteine peroxidase (cysteine: $\mathrm{H}_{2} \mathrm{O}_{2}$ oxidoreductase). The aim of the present study was to test the hypothesis of cysteine: $\mathrm{H}_{2} \mathrm{O}_{2}$ oxidoreductase activity in rat plasma. The rat plasma was found to be able to accelerate greatly the $\mathrm{H}_{2} \mathrm{O}_{2}$-dependent oxidation of cysteine. The activity was a characteristic of a protein fraction precipitated at $30-44 \%$ ammonium sulfate saturation, and the specific activity in protein fraction was significantly higher than in whole plasma. Cysteine: $\mathrm{H}_{2} \mathrm{O}_{2}$ oxidoreductase reaction stoichiometry (2:1 mole ratio) was detected for the catalyzed interaction between cysteine and $\mathrm{H}_{2} \mathrm{O}_{2}$. Estimation of cysteine peroxidase activity may be useful in research on the functioning of the antioxidant system.
\end{abstract}

Keywords: aminothiol, stoichiometry; 5,5'-dithiobis(2-nitrobenzoic acid); Ellman's reagent

\section{Introduction}

The enzymes of the glutathione peroxidase $(\mathrm{Gpx})$ family catalyze the reduction of inorganic $\left(\mathrm{H}_{2} \mathrm{O}_{2}\right)$ and organic peroxides. Glutathione $(\mathrm{GSH})$ is understood to be a natural reductant for Gpx (Toppo et al., 2009). However, some studies indicated other aminothiol reductants of peroxidases. Cysteine is an effective low-molecular-weight reductant for human extracellular glutathione peroxidase (Gpx3) (Takebe et al. 2002, Wolin 2011). Selenoprotein P and serum albumin are able to reduce phospholipid hydroperoxide with GSH, cysteine, or homocysteine (Hurst et al. 1999, Saito et al. 1999).

Recently, we demonstrated that rat plasma and human serum possess homocysteine peroxidase activity (Razygraev 2012a,b), which can be a property of Gpx3 as well as cysteine peroxidase activity demonstrated by Takebe et al. (2002). The Ellman's-reagentbased method using $\mathrm{H}_{2} \mathrm{O}_{2}$ as a peroxide substrate was applied in these recent studies. The aim of the present study was to test for cysteine: $\mathrm{H}_{2} \mathrm{O}_{2}$ oxidoreductase activity in rat plasma using the same Ellman's-reagent-based method.

\section{Materials \& Methods}

Animals were donated by the Rappolovo breeding farm of the Russian Academy of Medical Sciences. The plasma of adult female Wistar rats (4-7 months old) was obtained using ethylenediaminetetraacetate-containing tubes as described by Razygraev (2012a). The particular protein fractions were isolated by ammonium sulfate precipitation with centrifugation at $10,000 \mathrm{~g}$ for $10 \mathrm{~min}$ at $10^{\circ} \mathrm{C}$ (Burgess 2009), and then diluted in an appropriate volume of physiological saline $(0.9 \% \mathrm{NaCl})$.

To assay the activity utilizing cysteine with $\mathrm{H}_{2} \mathrm{O}_{2}$, the modified method of determination of Gpx activity (Razygraev 2004) was used, with the replacement of GSH by cysteine. Briefly, the reaction mixture consisted of $84 \mathrm{mM}$ Tris/ $\mathrm{HCl}$ buffer $(\mathrm{pH} 8.5), 0.28$ $\mathrm{mM}$ ethylenediaminetetraacetate, $19.2 \mathrm{mM} \mathrm{NaN}_{3}$, biological material (or its diluent), DLcysteine and $\mathrm{H}_{2} \mathrm{O}_{2}$ in appropriate concentrations. The temperature of incubation was $37^{\circ} \mathrm{C}$. The cysteine oxidation was started by the addition of $\mathrm{H}_{2} \mathrm{O}_{2}$ and stopped by the addition of 
trichloroacetic acid after an appropriate incubation time. The denatured proteins were pelleted by centrifugation, and the supernatants stained with Ellman's reagent to estimate the concentration of unreacted cysteine. The absorbance was read at $412 \mathrm{~nm}$. To determine the cysteine concentration, the 2-nitro-5-thiobenzoate extinction coefficient of $14,150 \mathrm{M}^{-1} \times \mathrm{cm}^{-1}$ was used (Riddles et al. 1979). Protein concentration was determined by using the Folin phenol reagent (the Lowry method) (Dawson et al. 1986).

Since the distribution of the data was unknown, the results were presented in the form of the median and 17th and 83th percentiles (Me [17\%; 83\%]). For the same reason, the activity levels in isolated protein fraction and plasma were compared using Wilcoxon's paired test (Glantz 1994).

\section{Results}

The $\mathrm{H}_{2} \mathrm{O}_{2}$-dependent oxidation of cysteine was greatly accelerated when the plasma was present in the reaction mixture. The dilution of rat plasma 260 -fold by the reaction mixture with preincubation times of $0-40 \mathrm{~s}$ did not affect the initial concentration of cysteine. The conditions used allow us to observe a constant rate of the $\mathrm{H}_{2} \mathrm{O}_{2}$-dependent oxidation of cysteine during the first $60 \mathrm{~s}$ after the addition of $\mathrm{H}_{2} \mathrm{O}_{2}$ (Fig. 1). Activity was proportional to protein concentration (Fig. 2).

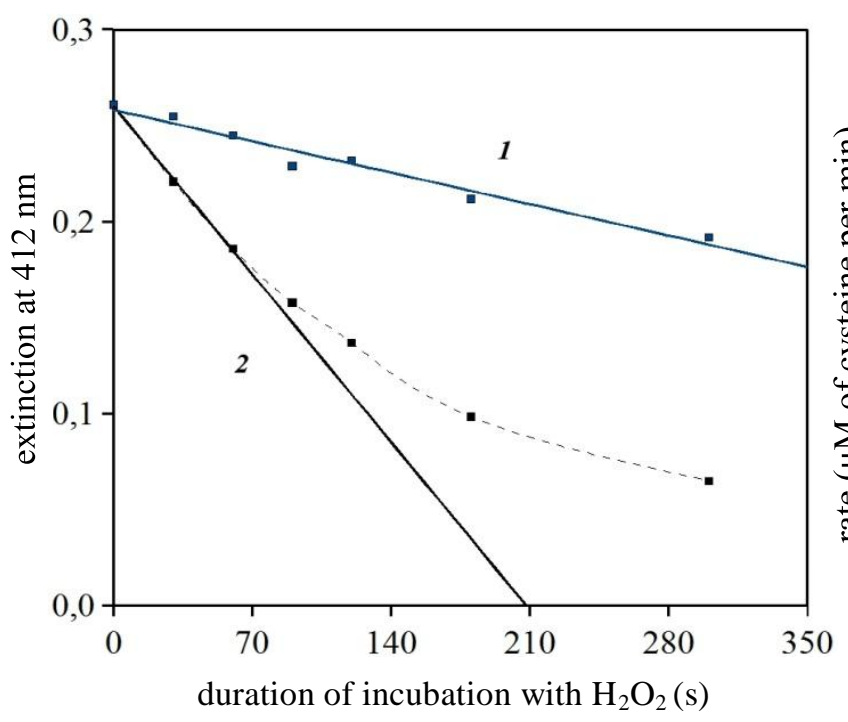

Figure 1: Cysteine oxidation by $\mathrm{H}_{2} \mathrm{O}_{2}$ in (1) the absence, and (2) the presence, of rat blood plasma. The $\mathrm{y}$-axis is the extinction at $412 \mathrm{~nm}$ developing due to the interaction of Ellman's reagent with unoxidized cysteine. A 260-fold dilution of plasma by the reaction mixture was used. The initial concentrations of DL-cysteine and $\mathrm{H}_{2} \mathrm{O}_{2}$ were 125 and 40.8 micromole/l, respectively.

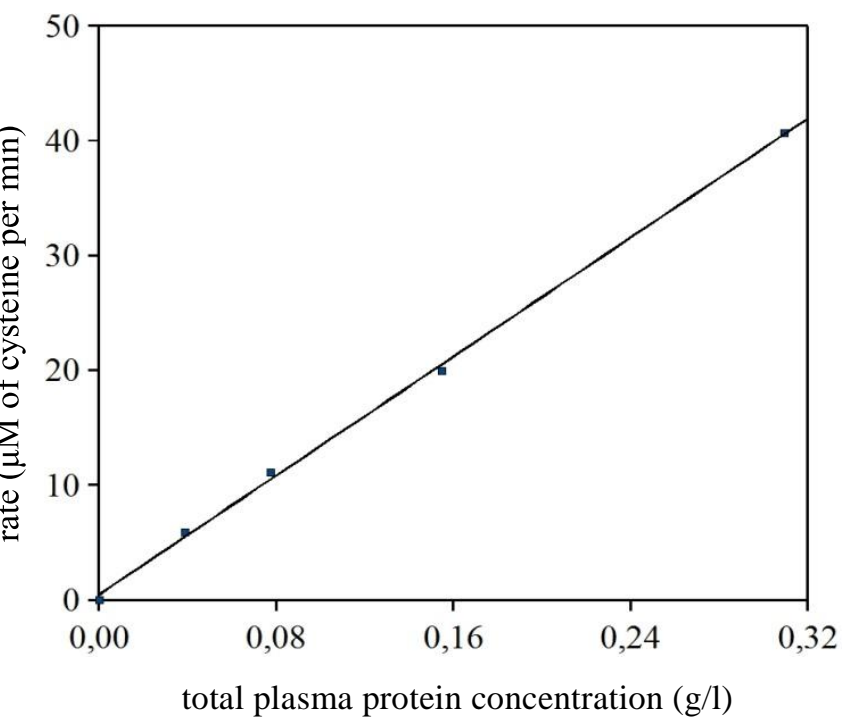

Figure 2: Effect of protein concentration on the rate of plasma-catalyzed oxidation of cysteine by $\mathrm{H}_{2} \mathrm{O}_{2}$. The initial concentrations of DL-cysteine and $\mathrm{H}_{2} \mathrm{O}_{2}$ were 125 and $40.8 \mu \mathrm{M}$, respectively. The incubation time was $40 \mathrm{~s}$.

The activity was revealed in the protein fraction precipitated in the range of ammonium sulfate saturation equal to $30-44 \%$. The specific activity in this protein fraction was significantly higher than in whole plasma. With $0.25 \mathrm{mM}$ DL-cysteine, the activity values expressed in nanomoles of cysteine/(min $\times \mathrm{mg}$ of protein) were 965.0 [904; 979] for the 
protein fraction, and 221.0 [204; 226] for whole plasma (the type I error probability was $3.125 \%, \mathrm{n}=6)$.

On the basis of maximal levels of cysteine oxidation caused by the presence of rat plasma protein fraction and measured at scarcity of $\mathrm{H}_{2} \mathrm{O}_{2}$, the $2: 1$ mole ratio was determined for the catalyzed interaction between cysteine and hydrogen peroxide. With $0.25 \mathrm{mM}$ DLcysteine and $41.8 \mu \mathrm{M}$ peroxide, the values of the maximal cysteine concentration decrease expressed in $\mu \mathrm{M}$ were $82.6[81.4 ; 83.8]$ and $83.3[81.4 ; 84.8]$ ( $\mathrm{n}=6$ for each series).

\section{Discussion}

The acceleration of $\mathrm{H}_{2} \mathrm{O}_{2}$-dependent oxidation of cysteine caused by the rat plasma supports the hypothesis of the existence of rat plasma cysteine peroxidase activity. The most probable explanation for this is the ability of rat Gpx-3 to use the cysteine as a reductant instead of GSH, analogous to human Gpx-3 (Takebe et al. 2002). Similarly to human Gpx-3, the rat plasma protein fraction possessing the activity is precipitated at relatively low saturation by ammonium sulfate (Broderick et al. 1987).

Since the activity found is a characteristic of the plasma protein fraction, it supports the hypothesis of the enzymatic character of the catalysed oxidation of cysteine by hydrogen peroxide. The significant increase in activity following fraction isolation is also predictable if this hypothesis were valid.

Analogously to the Gpx reaction (Toppo et al. 2009), the catalyzed interaction between cysteine and $\mathrm{H}_{2} \mathrm{O}_{2}$ can be described by the following scheme including stoichiometric coefficients:

$$
\text { 2Cys- } \mathrm{SH}+\mathrm{H}_{2} \mathrm{O}_{2} \rightarrow \text { Cys-S-S-Cys }+2 \mathrm{H}_{2} \mathrm{O} \text {, }
$$

where the Cys-SH and Cys-S-S-Cys designate cysteine and cystine (the oxidized form of cysteine), respectively. The stoichiometry of this reaction is 2 moles of cysteine to 1 mole of hydrogen peroxide. Our results indicate the same mole ratio and thus support the assumption that the observed $\mathrm{H}_{2} \mathrm{O}_{2}$-dependent oxidation of cysteine caused by the rat plasma is the cysteine: $\mathrm{H}_{2} \mathrm{O}_{2}$ oxidoreductase activity.

The results presented here represent the minimal set of data that permits the conclusion that the hypothesis of cysteine: $\mathrm{H}_{2} \mathrm{O}_{2}$ oxidoreductase activity in rat plasma is valid. Further purification and characterization of the enzyme will indicate whether the Gpx-3 causes the plasma cysteine: $\mathrm{H}_{2} \mathrm{O}_{2}$ oxidoreductase activity in rats. A study of the kinetic properties of this enzymatic activity is also needed.

The cysteine SH-form is more abundant in plasma than GSH (Wolin 2011), but there is a little attention paid to the enzymatic reduction of hydroperoxides by cysteine in plasma. The measurement of cysteine peroxidase activity might have useful applications in further studies of the antioxidant system.

\section{Acknowledgements}

I would like to thank Professor A.V. Arutjunyan and Dr Zh.N. Tumasova for assistance. I would also like to thank Dr G.O. Kerkeshko for his help in finding the articles.

\section{References}

Broderick DJ, Deagen JT \& Whanger PD (1987) Properties of glutathione peroxidase isolated from human plasma. Journal of Inorganic Biochemistry 30: 299-308

Burgess RR (2009) Protein precipitation techniques. Methods in Enzymology 463: 331-342

Dawson RMC, Elliott DC, Elliott WH \& Jones KM (1986) Data for Biochemical Research. 3rd edition. Oxford: Oxford Science Publications, OUP.

Glantz S (1994) Primer of biostatistics. 4th edition. New York: McGraw-Hill. 
Hurst R, Bao Y, Ridley S \& Williamson G (1999) Phospholipid hydroperoxide cysteine peroxidase activity of human serum albumin. Biochemical Journal 338: 723-728

Razygraev AV (2004) Method of determination of glutathione peroxidase activity using hydrogen peroxide and 5,5'-dithiobis(2-nitrobenzoic acid). Kliniko-Laboratornyj Konsilium (4): 19-22 (in Russian)

Razygraev AV (2012a) Catalytic activity in rat blood plasma and erythrocytes that eliminates homocysteine with hydrogen peroxide. Biomedicinskaja Khimija 58(5): 592-598 (in Russian)

Razygraev AV (2012b) Homocysteine peroxidase activity in human serum. Kliniko-Laboratornyj Konsilium (44): 16-20 (in Russian)

Riddles PW, Blakeley RL \& Zerner B (1979) Ellman's reagent: 5,5'-dithiobis(2-nitrobenzoic acid) - a reexamination. Analytical Biochemistry 94(1): 75-81

Saito Y, Hayashi T, Tanaka A, Watanabe Y, Suzuki M, Saito E \& Takahashi K (1999) Selenoprotein P in human plasma as an extracellular phospholipid hydroperoxide glutathione peroxidase. Isolation and enzymatic characterization of human selenoprotein P. Journal of Biological Chemistry 274(5): 28662871

Takebe G, Yarimuzu J, Saito Y, Hayashi T, Nakamura H, Yodoi J, Nagasawa S \& Takahashi K (2002) A comparative study on the hydroperoxide and thiol specificity of the glutathione peroxidase family and selenoprotein P. Journal of Biological Chemistry 277(43): 41254-41258

Toppo S, Flohe L, Ursini F, Vanin S \& Maiorino M (2009) Catalytic mechanisms and specificities of glutathione peroxidases: variations of a basic scheme. Biochimica et Biophysica Acta - General Subjects 1790(11): 1486-1500

Wolin MS (2011) Plasma glutathione peroxidase activity is potentially a key regulator of vascular diseaseassociated thrombosis. Circulation 123: 1923-1924

$$
\begin{aligned}
& \text { الملخص العربيى } \\
& \text { نشاط إنزيم سيتوزين بيرو أكسيديز فى بلازما دم فئر ان التجارب }
\end{aligned}
$$

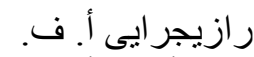

$$
\begin{aligned}
& \text { معهد أوت لأمر اض النساء و التوليد - مينديليفسكاثا - سانت بيتربيرج - روسيا }
\end{aligned}
$$

أوضحت در اسات سابقة أن الجلوتاثايون بيرو أكسيديز يمكن أن بعمل مثل سيتوزين بيرو أكسيديز (cysteine:H2O

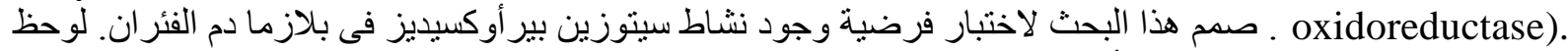
قدرة بلازما دم الفئران فى تسريع أكسدة

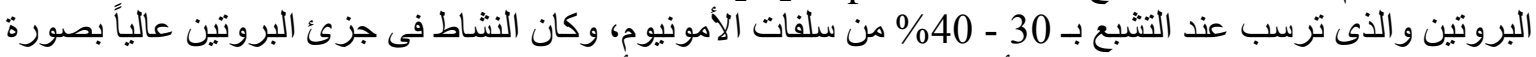
معنوية عن البلازما بشكل عام. ووضتح أن تفاعل سيتوزين - He

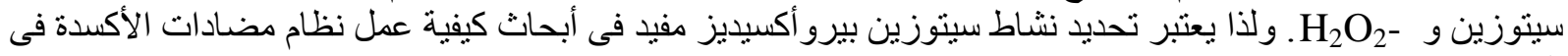

